\title{
CLINICAL AND MOLECULAR CYTOGENETIC CHARACTERISATION OF CHILDREN WITH DEVELOPMENTAL DELAY AND DYSMORPHIC FEATURES KLINIČNA IN MOLEKULARNA CITOGENETSKA OBRAVNAVA OTROK Z RAZVOJNIM ZAOSTANKOM IN DISPLASTIČNIMI ZNAKI
}

\author{
Sara BERTOK ${ }^{1, *}$, Mojca ŽERJAV TANŠEK ${ }^{1}$, Primož KOTNIK ${ }^{1,2}$, Tadej BATTELINO ${ }^{1,2}$, Marija VOLK $^{3}$, \\ Vanna PECILE ${ }^{4}$, Lisa CLEVA ${ }^{4}$, Paolo GASPARINI ${ }^{4}$, Jernej KOVAČ ${ }^{5}$, Tinka HOVNIK ${ }^{5}$
}

${ }^{1}$ University Medical Centre Ljubljana, University Children’s Hospital, Department of Pediatric Endocrinology, Diabetes and Metabolic Diseases, Bohoriceva 20, 1000 Ljubljana, Slovenia

2University of Ljubljana, Faculty of Medicine, Vrazov trg 2, 1000 Ljubljana, Slovenia

${ }^{3}$ University Medical Centre Ljubljana, Clinical Institute of Medical Genetics, Department of Obstetrics and Gynaecology, Slajmerjeva 4,1000 Ljubljana, Slovenia

${ }^{4}$ Institute for Maternal and Child Health-IRCCS “Burlo Garofolo”, via dell'Istria, 65/1, 34137 Trieste, Italy

5University Medical Centre Ljubljana, University Children's Hospital, Unit for Special Laboratory Diagnostics, Vrazov trg 1, 1000 Ljubljana, Slovenia

\section{ABSTRACT}

Keywords:

copy number variations, CGH-array, SNP-array, FISH

\section{IZVLEČEK}

Ključne besede:

variacije $v$ številu kopij, CGH-mikromreže, SNP-mikromreže, FISH
Introduction. Developmental delay and dysmorphic features affect 1 - $3 \%$ of paediatric population. In the last few years molecular cytogenetic high resolution techniques (comparative genomic hybridization arrays and single-nucleotide polymorphism arrays) have been proven to be a first-tier choice for clinical diagnostics of developmental delay and dysmorphic features.

Methods and results. In the present article we describe the clinical advantages of molecular cytogenetic approach (comparative genomic hybridization arrays and single nucleotide polymorphism arrays) in the diagnostic procedure of two children with developmental delay, dysmorphic features and additional morphological phenotypes. Additionally, we demonstrate the necessity of fluorescent in situ hybridization utilisation to identify the localisation and underlying mechanism of detected chromosomal rearrangement.

Conclusions. Two types of chromosomal abnormalities were identified and confirmed using different molecular genetic approaches. Comparative genomic hybridization arrays and single nucleotide polymorphism arrays are hereby presented as important methods to identify chromosomal imbalances in patients with developmental delay and dysmorphic features. We emphasize the importance of molecular genetic testing in patients' parents for the demonstration of the origin and clinical importance of the aberrations prior determined in the patients. The results obtained using molecular cytogenetic high resolution techniques methods are the cornerstone for proper genetic counselling to the affected families.

Uvod. Razvojni zaostanek in displastične znake ugotavljamo pri 1-3\% otrok. Molekularne citogenetske tehnike z visoko ločljivostjo (CGH- in SNP-mikromreže) so $v$ zadnjih letih postale ključna preiskava $v$ rutinski klinični diagnostiki pri preiskovancih z razvojnim zaostankom, displastičnimi znaki in drugimi nepravilnostmi.

Metode in rezultati. $V$ prispevku želimo prikazati klinične prednosti molekularnega citogenetskega pristopa $v$ diagnostičnem postopku dveh otrok z razvojnim zaostankom, displastičnimi znaki in drugimi nepravilnostmi. Potrditev kromosomske preureditve z metodo FISH je potrebna za opredelitev točne kromosomske lokacije in mehanizma nastanka kromosomske nepravilnosti.

Zaključek. V prispevku predstavljamo dva tipa kromosomskih nepravilnosti, ki smo jih ugotovili in potrdili z različnimi molekularnimi metodami. Poudariti želimo pomen potrjevanja in analize pri starših za opredelitev izvora nastanka kromosomske preureditve. Rezultati genetske preiskave so ključni pri genetskem svetovanju prizadetim posameznikom in njihovim družinam. 


\section{INTRODUCTION}

Developmental delay (DD) and dysmorphic features are common in the paediatric practice affecting $1-3 \%$ of children (1). Although the aetiology is heterogeneous, microscopic and submicroscopic copy number variants (CNVs) are among the most common genetic causes $(2,3)$. It has been shown that molecular karyotyping should be a first-tier clinical diagnostic test for individuals with DD and dysmorphic features $(4,5)$ as clinically relevant CNVs have been detected in $10-20 \%$ of cases (6). Introduction of comparative genomic hybridization arrays (CGH-array) and single-nucleotide polymorphism arrays (SNP-array) have revolutionized the molecular cytogenetic diagnostics in the past few years (7). CGH- and SNP-arrays allow the mapping of genomic imbalance at submicroscopic level, thereby directly linking disease phenotypes to gene dosage alterations (8). At the same time fluorescent in situ hybridization (FISH) analysis remains an important tool for confirmation and chromosomal identification of detected genomic imbalances and their breakpoints.

We report the case of two children with DD, dysmorphic features and additional morphological phenotypes. Additionally, the identification of chromosomal rearrangement using different molecular cytogenetic techniques is described, and the clinical usefulness of molecular cytogenetic approaches in the diagnostic procedure discussed.

\section{CLINICAL ASSESSMENT OF PATIENTS}

\subsection{Case 1}

A 12-year-old girl with developmental delay, dysmorphic features, epilepsy, obesity, hypercholesterolemia and hypoplastic posterior corpus callosum is presented. She is treated at the Department for paediatric endocrinology, diabetes and metabolism at University Children's Hospital in Ljubljana, Slovenia. The girl was born at term after uneventful pregnancy to healthy non-consanguineous parents. Birth weight was $2890 \mathrm{~g}(10-25 \mathrm{P})$, and the birth length $47 \mathrm{~cm}(10 \mathrm{P})$; head circumference $(\mathrm{HC})$ data was not given. She had feeding difficulties in the first few weeks of life. Speech and motor developmental delay was observed in early childhood. At the age of 5 years, epilepsy was diagnosed. Head MR showed hypoplastic posterior corpus callosum. Thereafter, she gained excessive weight and hypercholesterolemia was diagnosed. At 11 years of age, her height was $161 \mathrm{~cm}(99 \mathrm{P})$, she weighted $68.75 \mathrm{~kg}$ (100 P), HC $52.2 \mathrm{~cm}$ (50\%), and a marked developmental speech delay was determined. The following facial dysmorphic features were described: thin, long face, high forehead, full cheeks, deep naso-labial sulcus, small mouth, high vaulted palate and thin, long and flat philtrum. The eyes were wide open, while the neck was short with low-set hairline and ears. The nipples were widely spaced.

\subsection{Case 2}

A 13-year-old boy with developmental delay, dysmorphic features, atrial septal defect and recurrent infections is presented. He is treated at the Institute for Maternal and Child Health-IRCCS ‘Burlo Garofolo,' Trieste, Italy. He was born to healthy non-consaguine parents with no diagnosed Mendelian disorders or neurologic disorders in the family. Apart from heart abnormality and frequent infections, no additional relevant findings were determined. Ophtamologic and otorynolaringologic examinations were normal. Aged 7 years, 10 months, the presence of mild dysmorphic features was determined, namely: wide forehead, telecanthus, flat line (malar bone hypoplasia) and thick lips.

\section{METHODS}

All cytogenetics and molecular-cytogenetics analyses were performed with written and signed informed consent. Cytogenetic postnatal analyses were carried out on peripheral blood lymphocytes from patients and their parents. Genomic DNA was extracted from whole blood, using FlexiGene DNA isolation kit (Qiagene $\mathrm{GmbH}$, Hilden, Germany).

\subsection{Cytogenetic and FISH Analysis}

Chromosome analysis using GTG banding on metaphases was performed according to standard procedures. Additional FISH experiments were undertaken using locus specific and sub-telomere FISH probes (BlueGnome and Vysis, Abbott). Hybridization and washing was done according to the manufacturer's protocol, and a minimum of 100 interphase cells was analyzed. Chromosomes were counterstained with 4',6-diamidino-2-phenylindole, and images were captured using the CytoVysion Imaging System.

\subsection{Comparative Genomic Hybridization Microarray}

DNA was hybridized to Agilent 60K human CGH microarray (Agilent Technologies, Inc., Santa Clara, Calif., USA). Discovered copy number variants were identified using Agilent CytoGenomics edition 2.0.6.0 software and interpreted according to the publicly available databases: Database of Genomic Variants (http://projects.tcag.ca/ variation/gbrowse/hg19), PubMed and ISCA database (http://www. iscaconsortium.org/).

\subsection{Single Nucleotide Polymorphism Microarray}

DNA was processed using the Illumina HumanCNV370Quad/OmniExpress genotyping microarray according to the protocol. Data analysis was performed using the Illumina GenomeStudio v.2011 and Illumina cnvPartition (ver 3.2.0) software program. 


\section{RESULTS}

In the first case, postnatal CGH-array revealed $5.4 \pm 0.05$ Mb duplication at the cytoband location 17p13.3p13.2 in the absence of additional relevant submicroscopic aberrations. Conventional cytogenetic analysis on metaphases from peripheral blood showed an unbalanced karyotype with an additional chromosomal material on chromosome 20. Partial trisomy of the segment 17p13.2 was confirmed with FISH probe specific for region 17p13.2 (Figure 1). Parental chromosomal analysis showed that derivative chromosome 20 was inherited from the mother, a carrier of apparently balanced reciprocal translocation between chromosomes 17 and 20 (Figure 2).

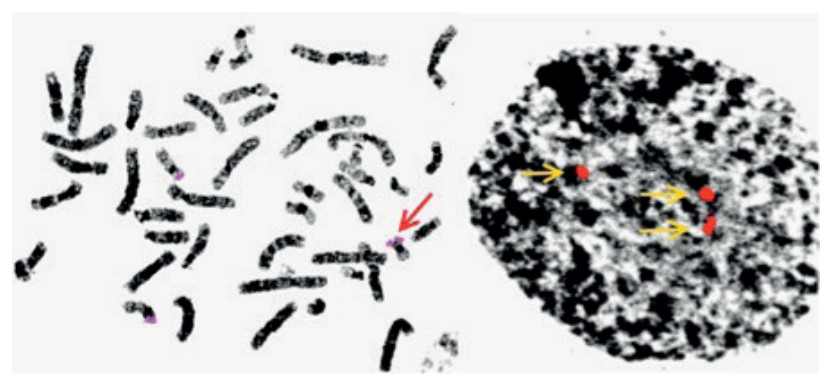

Figure 1. The subject's metaphase (left) and interphase (right) FISH for region 17p13.2 (RP11-104019; Blue Gnome, UK). The red arrow indicates the signal (pink) of the probe on chromosome 20 . The yellow arrows indicate three signals (red) in interphase nucleus for region 17p13.2.
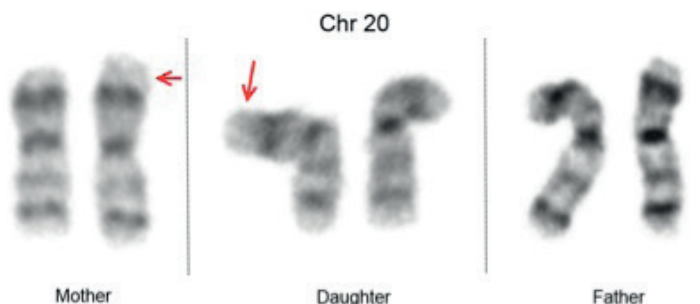

Figure 2. The comparison of mother's, daughter's and father's chromosome 20. The red arrow indicates the slightly enlarged region where the material of chromosome 17 is present.

In the second case, postnatal karyotype analysis carried out on lymphocytes was considered normal (46, XY). Furthermore, SNP array analysis (Figure 3) revealed a duplication of $14.9 \mathrm{Mb}$ in the $4 \mathrm{p} 16.3 \mathrm{p} 15.33$ regions and a deletion of $14 \mathrm{Mb}$ in the $4 \mathrm{q} 34.2 \mathrm{q} 35.2$ regions. The parents refused to be submitted to analysis.

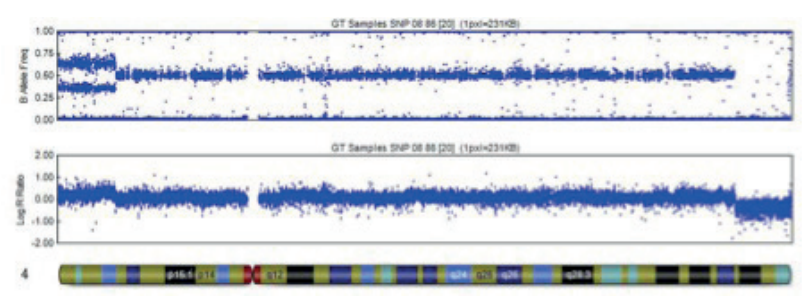

Figure 3. The results of SNP array [arr 4p16.3p15.33(17,764-15, $392,559) \times 3,4 q 34.2 q 35.2(176,447,305-190,977,969)$ $x 1]$ revealing the presence of rearranged chromosome 4 .

\section{DISCUSSION}

Two children with developmental delay and dysmorphic features are presented. Using different molecular cytogenetic approaches they were both found to harbour genomic imbalances.

In Case 1, the child inherited the derivative chromosome 20 from the mother, who is the carrier of the apparently balanced translocation between chromosomes 17 and 20. Partial trisomy 17pter is causative for the phenotype of the proband, and is consistent with 17p13 microduplication syndrome (9). The duplication sizes in previously reported cases varied from 0.24 to $4.0 \mathrm{Mb}$, and their phenotype mainly depends on altered expression of PAFAH1B1 gene (10). There are nine cases reported in the medical literature with a pure $17 \mathrm{p} 13$ microduplication syndrome caused by an interstitial duplication or a terminal duplication of 17p13. These patients had mild to moderate psychomotoric retardation and dysmorphic features, including high forehead, small mouth and nose, together with dysgenesis of corpus callosum ( 9 , 11). The expressed phenotype of our patient may be due to the synergistic effect of $17 p 13.3$ duplication and accompanying translocation that may cause the disruption of the gene at the translocation breakpoints. The short arm of chromosome 17 is particularly prone to submicroscopic rearrangements due to the presence of high density low copy repeats (LCRs) (12). The translocation of a small portion of chromosome 17, with only a p telomeric/subtelomeric cap on chromosome 20, is derived from a presumable mechanism of single-segment exchange (13). It has been suggested that reciprocal translocations are the result of recombination between repetitive sequences, such as between a variable number of tandem repeats or AT-rich regions, as observed in the case of the common recurrent translocation $t(11 ; 22)(14)$. Combining the results of CGH-array and FISH analysis, we can postulate that patients with unbalanced translocation involving 17pter chromosomal region, have similar clinical phenotype compared to pure 17p13 microduplication syndrome. Using CGH-array, the breakpoints in 17p13.2 region were identified, while FISH results revealed exact localization and mechanism of the chromosomal 
aberration. Nevertheless, the introduction of array technology into the routine clinical diagnostic procedures revealed a wide variety of new microduplication syndromes (15).

SNP-array in the second case revealed the duplication of $4 p$ and the deletion of $4 q$, which indicates the presence of recombinant chromosome 4 . Both the deletion and the duplication have approximately the same size and similar banding pattern, hence the aberration was not detected by conventional karyotyping. Recombinant chromosomes arise from pericentric inversion of parental origin (16). To date, 11 cases of a similar rearrangements have been reported (17). The recombinant chromosome 4 [rec(4) dup(4p)] is present in $80 \%$ of the viable recombinants (13), since the deletion seems to have more deleterious effect than large duplications (18). Interestingly, all cases in the literature have breakpoints within 4p13 4p15 and $4 q 35$ implicating a recurrent event between repetitive DNA sequences predisposing pericentric inversion at these hotspots. During meiotic crossing over chromosome with pericentric inversion may give rise to recombinants with duplicated $\mathrm{p}$ or duplicated $\mathrm{q}$ arm.

The association between specific chromosome 4 rearrangements and clinical features was not recognized within the earliest reports due to variations in the sizes of the $4 \mathrm{q}$ deletion, differences in the breakpoints, and variable expression of the partial trisomy of the $4 p(18)$. It has been suggested that $\operatorname{rec}(4) \operatorname{dup}(4 p)$ represents a discrete entity with consistent phenotype of growth retardation, microcephaly, dysmorphic features and genital anomalies. Additionally, 5 of 11 cases present with cardiac defect (19). Although recombinant chromosome 4 is a rare chromosomal anomaly, several genotypephenotype correlation studies have been conducted, revealing that urogenital and cardiac defects are probably due to the deletion of $4 q$, whereas other clinical features are likely due to $4 p$ duplication (19). It is now recognized that clinical features of patients with rec(4) are relatively consistent and specific to the regions of duplication or deletion (17). Since our case has similar clinical features compared to other reported cases, we can conclude that recombinant chromosome 4 syndrome can be diagnosed on the basis of clinical features and specific deleted and duplicated chromosomal regions. Using SNP-array and specific clinical features, the breakpoints and their origin can be precisely characterized even without parental analysis

\section{CONCLUSION}

CGH and SNP-arrays are ideal diagnostic tools to identify chromosomal imbalances, their breakpoints and origin in patients with developmental delay and dysmorphic features $(3,4,7,15)$. In addition, SNP-arrays may offer further information regarding segmental uniparental disomies and absences of heterozygosity when required.
On the other hand, FISH analysis is used to confirm the presence of chromosomal aberration and its exact location, revealing underlying mechanism of genomic rearrangement. In addition, follow-up parental studies are recommended to demonstrate the origin of the rearrangement, in order to offer more accurate genetic counselling to the families, while pre- and post-diagnostic genetic counselling should be available to anyone undergoing molecular karyotyping.

\section{CONFLICTS OF INTEREST}

The authors declare that no conflicts of interest exist.

\section{FUNDING}

The study was financed in part by the Slovenian National Research Agency grants J3-6800 J3-6798 and P3-0343.

\section{ETHICAL APPROVAL}

Written informed consent was obtained from all patients or/and their parents.

\section{REFERENCES}

1. Shevell M, Ashwal S, Donley D, Flint J, Gingold M. et al. Practice parameter: evaluation of the child with global developmental delay: report of the Quality Standards Subcommittee of the American Academy of Neurology and The Practice Committee of the Child Neurology Society. Neurology 2003; 60: 367-80.

2. Regier DA, Friedman JM, Marra CA. Value for money? Array genomic hybridization for diagnostic testing for genetic causes of intellectual disability. Am J Hum Genet 2010; 86: 765-72.

3. Bartnik M, Nowakowska B, Derwińska K, Wiśniowiecka-Kowalnik B, Kędzior M, Bernaciak J. et al. Application of array comparative genomic hybridization in 256 patients with developmental delay or intellectual disability. J Appl Genet 2014; 55: 125-44.

4. Battaglia A, Doccini V, Bernardini L, Novelli A, Loddo S. et al. Confirmation of chromosomal microarray as a first-tier clinical diagnostic test for individuals with developmental delay, intellectual disability, autism spectrum disorders and dysmorphic features. Eur J Paediatr Neurol 2013; 17: 589-99.

5. Miller DT, Adam MP, Aradhya S, Biesecker LG, Brothman AR. et al. Consensus statement: chromosomal microarray is a first-tier clinical diagnostic test for individuals with developmental disabilities or congenital anomalies. Am J Hum Genet 2010; 86: 749-64.

6. Koolen DA, Pfundt R, de Leeuw N, Hehir-Kwa JY, Nillesen WM. et al. Genomic microarrays in mental retardation: a practical workflow for diagnostic applications. Hum Mutat 2009; 30: 283-92.

7. Girirajan S, Rosenfeld JA, Coe BP, Parikh S, Friedman N, Goldstein A. et al. Phenotypic heterogeneity of genomic disorders and rare copynumber variants. N Engl J Med 2012; 367: 1321-31.

8. Vissers LE, Stankiewicz $P$ Microdeletion and microduplication syndromes. Methods Mol Biol 2012; 838: 29-75.

9. Roos L, Jonch AE, Kjaergaard S, Taudorf K, Simonsen H, HamborgPetersen B, Brondum-Nielsen $\mathrm{K}$ et al. A new micro-duplication syndrome encompassing the region of the Miller-Dieker (17p13 deletion) syndrome. J Med Genet 2007; 46: 703-10. 
10. Avela KI, Aktan-Collan K, Horelli-Kuitunen N, Knuutila S, Somer M. A microduplication on chromosome 17p13.1p13.3 including the PAFAH1B1 (LIS1) gene. Am J Med Genet A 2011; 155A: 875-9.

11. Bi W, Sapir T, Schelochkov O, Zhang F, Withers MA, Hunter JV, Levy T. et al. Increased LIS1 expression affects human and mouse brain development. Nat Genet 2009; 41: 168-77.

12. Capra V, Mirabelli-Badenier M, Stagnaro M, Rossi A, Tassano E, Gimelli S, Gimelli G. Identification of a rare 17p13.3 duplication including the BHLHA9 and YWHAE genes in a family with developmental delay and behavioural problems. BMC Med Genet 2012; 13: 93.

13. McKinlay Gardner RJ, Sutherland GR, Shaffer LG. Chromosome abnormalities and genetic counselling. 3rd edition. Oxford: University Press, 2004.

14. Shaffer LG, Lupski JR. Molecular mechanisms for constitutional chromosomal rearrangements in humans. Annu Rev Genet 2000; 34: 297-329.
15. Shinawi M, Cheung SW. The array CGH and its clinical applications. Drug Discov Today. 2008; 13: 760-70.

16. Gersan, Keagl. Principles of clincial cytogenetics. 2nd edition, 2005.

17. Hemmat M, Hemmat O, Anguiano A, Boyar FZ, El Naggar M. et al. Genotype-phenotype analysis of recombinant chromosome 4 syndrome: an array-CGH study and literature review. Mol Cytogenet 2013; 6: 17.

18. Garcia-Heras J, Martin J. A rec(4) dup $4 p$ inherited from a maternal inv(4)(p15q35): case report and review. Am J Med Genet 2002; 109: 226-30.

19. Battaglia A, Brothman AR, Carey JC. Recombinant 4 syndrome due to an unbalanced pericentric inversion of chromosome 4 . Am J Med Genet 2002; 112: 103-6. 